\title{
Corporate Reputation And Technical Efficiency: Evidence From The Chemical And Business Services Industries
}

Marty Stuebs, Baylor University, USA

Li Sun, Ball State University, USA

\begin{abstract}
Recent financial scandals have created uneasiness in our financial markets. This resulting crisis of confidence increases the importance of reliably assessing firm performance. How can investors and creditors confidently assess firm performance? Can firm reputation provide signals about firm performance and efficiency? The purpose of this paper is to examine the association between corporate reputation and efficiency, a dimension of firm performance. We obtain a measure of a firm's technical efficiency by using Data Envelopment Analysis (DEA), a non-parametric technique. We use firms from America's Most Admired Companies list of 2006 as our measure of firm reputation. Results support the hypothesis that firms with superior reputation operate more efficiently than matched firms in the business services $(S I C=73)$ and chemical $(S I C=28)$ industries. The results should be of interest to managers who engage in behavior leading to or maintaining a positive corporate reputation. Also, the results can increase individual investors' confidence in investing companies with superior reputation.
\end{abstract}

Keywords: corporate reputation; firm performance; technical efficiency; chemical industry; business services industry.

\section{INTRODUCTION}

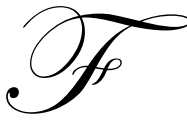

irm performance is an issue of increasing importance to investors especially after recent financial scandals and crises. Identifying signals of superior performance would be useful to investors and others. While other studies have examined the relation between corporate reputation and various financial performance measures, we explore the relationship between corporate reputation and a different dimension of firm performance. The purpose of this study is to examine the association between corporate reputation and technical efficiency.

This study uses a public measure - "America's Most Admired Companies" as a proxy for reputation. Fortune magazine has published annually a list of most-admired American companies since 1983. Firms selected on this list are considered to possess superior reputation. We use Data Envelopment Analysis (DEA) to measure technical efficiency. Since DEA produces relative efficiency scores, it should only be applied on an industry-byindustry basis to compare and calculate firm efficiency scores within an industry group of similar firms (i.e., compare "apples" to "apples"). We use two industries in our sample: the chemical industry (SIC = 28) and the business services industry ( $\mathrm{SIC}=73$ ). 15 chemical firms and 13 business service firms are identified on the list of America's Most Admired Companies of 2006. For each sample firm, a matching firm with the closest firm size within the same industry is selected.

Correlation coefficients, tests of differences in mean DEA efficiency scores between sample and matched firms, and regression analysis results all document and support a significant and positive relationship between corporate reputation and technical efficiency. The results suggest that firms with superior reputation operate more efficiently. These results add to other work that examines the relationship between reputation and financial 
performance. This paper also extends the work of Luchs et al. (2009) which established a positive relationship between reputation and the quality of reported performance. This paper explores the relationship between reputation and actual performance efficiency. The results should be of interest to managers who engage in behavior leading to or maintaining a positive corporate reputation. Also, the results can increase individual investors' confidence in investing in companies with superior reputation.

The rest of the paper is organized as follows. Section 2 presents prior research and develops our hypothesis. Section 3 presents variable measurement, sample selection, and initial statistics. Section 4 presents the empirical specification of the regression model and reports results. Section 5 concludes this study.

\section{LITERATURE REVIEW AND HYPOTHESES DEVELOPMENT}

Reputation is defined by Fombrun (1996, p.72) as "a perceptual representation of a company's past actions and future prospects that describe the firm's overall appeal to all its key constituents when compared to other leading rivals." Roberts and Dowling (2002) suggest that corporate reputation is a general organizational attribute that reflects the extent to which external stakeholders view the company as "good" or "bad". Strategic management theory suggests that good reputation may create competitive advantages for firms (Fombrun, 1996).

Research also views a good reputation as a unique asset to a firm. For example, Luchs et al. (2009) find that reputation is positively associated with an improved quality of reported performance. We extend this recent work by exploring the relationship between reputation and actual performance. The main drivers of reputation creation are various aspects of a company's actual performance (Dowling, 2001). A large body of empirical research (e.g. Dierickx and Cool, 1989; Fombrun and Shanley, 1990; Herremans et al., 1993; Landon and Smith, 1997) has examined the relation between a firm's reputation and its operating performance. It appears that existing empirical studies support a positive relationship between reputation and various dimensions of operating performance. We extend this work by exploring the relationship between reputation and firm efficiency - another dimension of firm performance.

Recent work supports a hypothesis of a positive relation between reputation and performance efficiency. For example, Roberts and Dowling (2002) suggest that firms with good reputations reap cost advantages since employees prefer to work for firms with good reputations and work harder. Also, suppliers prefer to do business with high-reputation firms in order to reduce contractual hazards. Therefore, firms with superior reputation are better able to maintain superior profitability through cost savings and operating efficiencies. The hypothesis is as follows:

Ha: There is a positive association between firm reputation and technical efficiency.

3. VARIABLE MEASUREMENT, SAMPLE SELECTION AND INITIAL STATISTICS

\subsection{The Dependent Performance Measurement Variable - Technical Efficiency}

We measure firm efficiency by using Data Envelopment Analysis (DEA) - a nonparametric model. Charnes et al. (1978, p.429) describes DEA as "a mathematical programming model applied to observational data that provides a new way of obtaining empirical estimates of relations that are cornerstones of modern economics." DEA models produce measures of performance efficiency - the production of outputs with quantities of inputs. Cooper et al. (2000) suggest that this DEA performance efficiency measure is a better, more comprehensive performance measure than other more traditional financial performance measures. First, DEA is a more general, flexible, and adaptable measure of firm performance. DEA does not require a prescribed functional form such as the Cobb-Douglas production function. DEA also does not require users to assign weights to each input and output. Second, unlike the typical parametric approach that compares each decision making unit (DMU) ${ }^{1}$ to an average DMU, DEA compares each DMU to the 'best' DMU. For these reasons, we use DEA to measure firm performance in our study.

The term 'best' is used here to mean that the (outputs/inputs) ratio for each DMU is maximized, relative to all other DMUs. For each DMU, DEA creates weights for inputs $\left(v_{i}\right)$ and outputs $\left(u_{i}\right)$ : 
Input $=v_{1} x_{10}+\ldots+v_{m} x_{m 0}$

Output $=u_{1} y_{10}+\ldots+u_{s} y_{s 0}$

DEA determines the 'best' input and output weights that maximize the (outputs/inputs) ratio for each individual DMU by using linear programming techniques. Each DMU's 'best' set of weights may differ from other DMUs.

Figure 1 shows a simple example of DEA. Assume one input and one output and a variable-return-to-scale production function. Suppose there are only 5 DMUs, (A, B, C, D, and E).

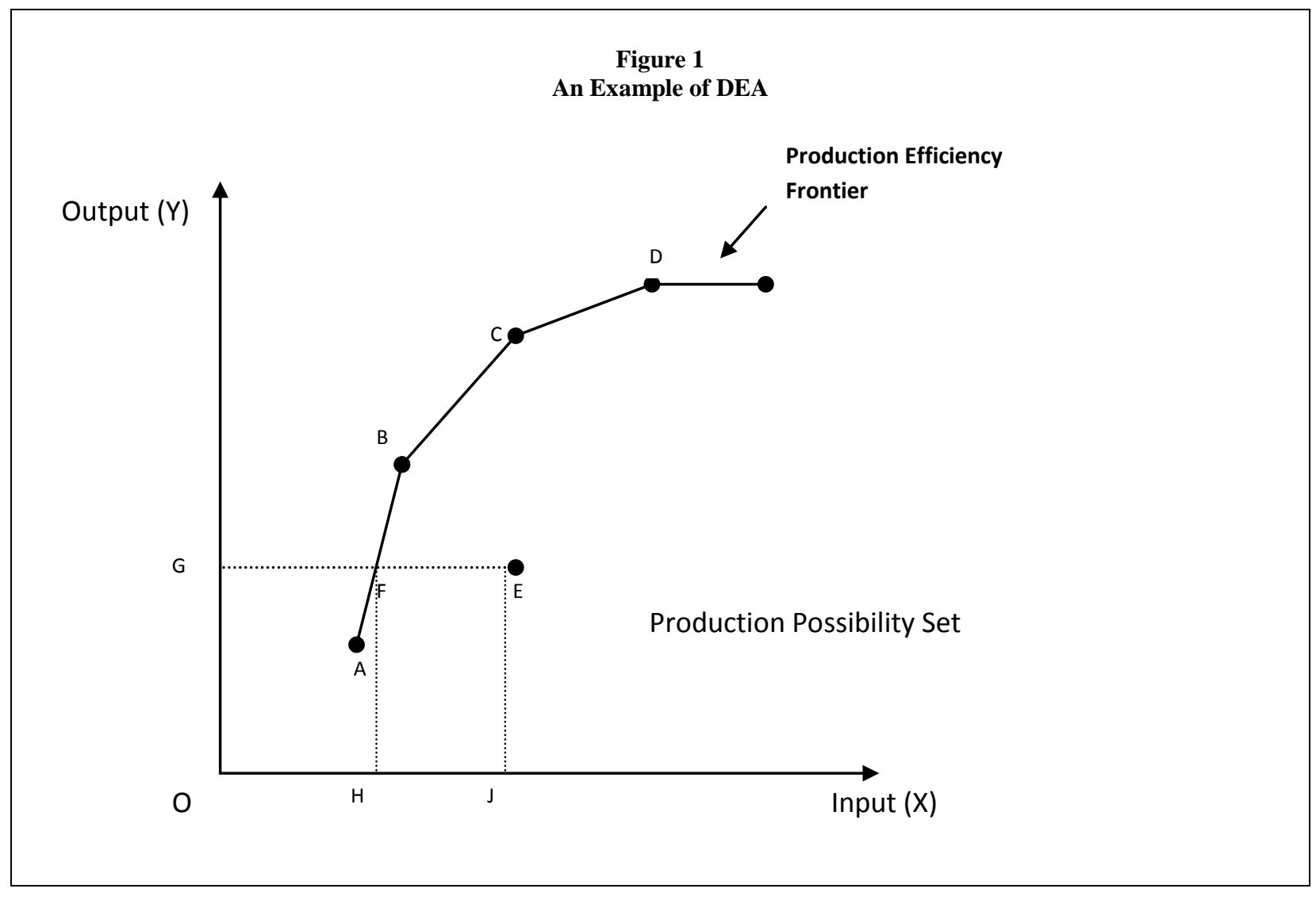

DMUs (A, B, C, D) are on the production efficiency frontier, and thus their values for the (outputs/inputs) ratio are one. The values of the (outputs/inputs) ratio for DMUs which operate beneath the production efficiency frontier are between zero and one. For instance, the efficiency of DMU (point) E is GF/GE. ${ }^{2}$

The first step in a DEA analysis is to select a specific DEA model. This study applies the variable-returnto-scale DEA model, also known as the BCC model (Banker et al., 1984). It is recommended by Cooper et al. (2000) to use the BCC model if there are multiple inputs or outputs involved in DEA studies. The BCC model estimates the efficiency of DMUs by solving the following linear program:

Max

$$
z=u \cdot y_{0}-u_{0}
$$


Subject to

$$
\begin{aligned}
& v \cdot x_{0}=1 \\
& -v \cdot x+u \cdot y-u_{0} e \leq 0 \\
& v \geq 0, u \geq 0, u_{0} \text { free in sign }
\end{aligned}
$$

Where

$\mathrm{x}, \mathrm{y}$ represent vectors of inputs and outputs respectively.

$z$ and $u_{0}$ are scalars.

$u_{0}$ may be positive or negative.

$e$ denotes a row vector in which all elements are equal to 1 .

$v$ and $u$ denote weights associated with a particular DMU.

Selecting input and output variables to use in the DEA model is the next task. Physical measures and monetary measures are common types of input / output variables. We use monetary measures for three reasons. First, it is difficult to obtain variable information in physical units. Second, Battese and Coelli (1995) suggest that it is preferable to use monetary measures to measure efficiencies at the firm level since a firm is often engaged in many different activities. Third, using monetary measures may capture more information.

Selecting specific monetary input and output variables for our DEA model is the next step. Feroz et al. (2008) argue that accounting measures like ROA and ROI may generate inconclusive performance results since these measures are measure-specific and can be affected by non-value-added factors. Instead, Feroz et al. (2008) suggest that incorporating traditional accounting variables, such as sales and cost of goods sold, into a DEA model may produce a more comprehensive measure of firm performance. Consistent with Feroz et al. (2008), we include two conventional input variables (cost of goods sold and selling, general and administrative expenses) and one conventional output variable (sales) in our DEA model. Table 1 summarizes these variables.

Table 1

Variable Selection for Efficiency Model

\section{Panel A: Output Variable}

\begin{tabular}{|l|l|l|}
\hline \multicolumn{1}{|c|}{ Variable Name } & \multicolumn{1}{|c|}{ Measurement } & \multicolumn{1}{c|}{ Description } \\
\hline $\begin{array}{l}\text { Sales } \\
\text { (Compustat Item \#12) }\end{array}$ & in dollars & $\begin{array}{l}\text { This variable represents sales after any } \\
\text { discounts, returned sales and } \\
\text { allowances for which credit is given to } \\
\text { customers. }\end{array}$ \\
\hline
\end{tabular}

Panel B: Input Variables

\begin{tabular}{|l|l|l|}
\hline \multicolumn{1}{|c|}{ Variable Name } & \multicolumn{1}{c|}{ Measurement } & \multicolumn{1}{c|}{ Description } \\
\hline $\begin{array}{l}\text { Cost of Goods Sold (COGS) } \\
\text { (Compustat Item \# 41) }\end{array}$ & in dollars & $\begin{array}{l}\text { This item represents all costs directly } \\
\text { allocated to production, such as direct } \\
\text { materials, direct labor and overhead. }\end{array}$ \\
\hline $\begin{array}{l}\text { Selling, General and Administrative } \\
\begin{array}{l}\text { Expenses (XSGA) } \\
\text { (Compustat Item \#189) }\end{array}\end{array}$ & in dollars & $\begin{array}{l}\text { This item represents expenses incurred } \\
\text { in the regular course of business. }\end{array}$ \\
\hline
\end{tabular}

Since DEA compares each DMU's (outputs / inputs) ratio to the 'best' DMU, DEA models produce relative efficiency scores. Because DEA produces relative efficiency scores, a firm's DEA score should only be calculated within an industry of similar firms. We use two industries in our sample: the chemical industry $($ SIC $=28)$ and the business services industry (SIC = 73). Reputation is important for chemical firms, and it is becoming more important for business services firms in light of recent corporate scandals and crises. A key factor in the success of chemical and business service firms is the trust between the firm and its clients. Because of the importance of 
reputation in these industries, recent work focused attention on the relationship between corporate social responsibility (CSR) and firm performance in the chemical (Griffin and Mahon, 1997) and banking (Simpson and Kohers, 2002) industries. A primary reason for investing in CSR activities in these industries is to improve firm reputation. We extend this work by examining the relation between reputation and firm performance in the chemical and business services industries.

\subsection{Sample Selection and Descriptive Statistics}

We use the list of America's Most Admired Companies as a proxy for good corporate reputation consistent with prior work (e.g. McLaughlin et al., 1996; Robert and Dowling, 2002; Damodaran, 2003; Anderson and Smith, 2006; Wang and Smith, 2008). Since the list of America's Most Admired Companies of 2006 was published in March 2006, we use the prior year's financial data (2005) in our analysis.

The full list of America's Most Admired Companies ${ }^{3}$ consists of 303 firms for 2006. Financial data are collected from Compustat. This study identifies 15 chemical firms and 13 business services firms with complete data. For each sample firm, a matched firm with the closest firm size (measured by total assets) within the same industry ${ }^{4}$ is selected.

Table 2

Descriptive Statistics

Chemical Industry (SIC=28)

Descriptive Statistics

\begin{tabular}{ccccccc}
\hline & \multicolumn{3}{c}{ Sample Firms $(\mathbf{n}=\mathbf{1 5})$} & & \multicolumn{3}{c}{ Matched Firms (n=15) } \\
\cline { 6 - 8 } Variable & Mean & Std. Dev. & Median & Mean & Std. Dev. & Median \\
\hline TA & $25,541.630$ & $20,835.000$ & $24,580.800$ & $23,938.590$ & $19,193.000$ & $15,469.000$ \\
TD & $14,807.130$ & $13,091.000$ & $8,846.000$ & $13,707.650$ & $10,723.000$ & $10,669.640$ \\
REV & $22,834.630$ & $19,491.000$ & $12,430.000$ & $15,638.100$ & $11,502.000$ & $15,394.600$ \\
COGS & $11,111.900$ & $12,009.000$ & $4,778.000$ & $4,082.855$ & $2,235.000$ & $3,757.230$ \\
XSGA & $6,633.019$ & $6,426.000$ & $3,998.300$ & $7,314.409$ & $5,902.000$ & $6,115.000$ \\
CFO & $3,704.332$ & $3,586.000$ & $2,578.800$ & $3,288.299$ & $3,095.000$ & $1,811.830$ \\
LEV & 0.605 & 0.163 & 0.648 & 0.627 & 0.250 & 0.600 \\
DEA & 0.863 & 0.107 & 0.877 & 0.791 & 0.071 & 0.799 \\
\hline
\end{tabular}

Paired Difference in Mean

\begin{tabular}{ccc}
\hline Variable & t test & Wilcoxon test \\
\hline TA & (p-value) & $(\mathrm{p}$-value $)$ \\
TD & 0.8281 & 0.9345 \\
REV & 0.8032 & 0.9835 \\
COGS & 0.2284 & 0.3909 \\
OEXP & 0.034 & 0.348 \\
CFO & 0.7645 & 0.7424 \\
LEV & 0.7363 & 0.7116 \\
DEA & 0.7819 & 0.6814 \\
\hline
\end{tabular}

Variable definition:

$\mathrm{TA}=$ total assets (Compustat Item \#6) in 2005.

$\mathrm{TD}=$ total debt (Compustat Item \#9 + \#34) in 2005.

$\mathrm{REV}=$ total revenue (Compustat Item \#12) in 2005.

COGS $=$ total cost of goods sold (Compustat Item \#41) in 2005.

$\mathrm{XSGA}=$ total selling, general and administrative expenses (Compustat Item \#189) in 2005.

$\mathrm{CFO}=$ total cash flow from operations (Compustat Item \#308) in 2005.

$\mathrm{LEV}=$ total debt (Compustat Item \#9 + \#34) / total assets (Compustat Item \#6).

$\mathrm{DEA}=$ efficiency score at firm level. 
Table 2 presents the descriptive statistics of selected variables for sample and matched firms in the chemical industry (SIC $=28$ ). These variables include total assets $(\mathrm{TA})$, debt $(\mathrm{TD})$, revenue $(\mathrm{REV})$, cost of goods sold (COGS), selling and administrative expenses (XSGA), cash flow from operations (CFO), leverage (LEV), and the DEA efficiency score (DEA). The mean and median values for the efficiency score are 0.863 and 0.877 , respectively, for sample firms compared to 0.791 and 0.799 , respectively, for matched firms. This result supports our hypothesis. Sample firms with better reputations in the chemical industry have statistically higher average efficiency scores (Wilcoxon test: $\mathrm{p}=0.0394$, $\mathrm{t}$ test: $\mathrm{p}=0.0379$ ).

Table 3

Descriptive Statistics

Business Services Industry (SIC=73)

\begin{tabular}{|c|c|c|c|c|c|c|}
\hline \multicolumn{7}{|c|}{ Descriptive Statistics } \\
\hline & \multicolumn{3}{|c|}{ Sample Firms $(n=13)$} & \multicolumn{3}{|c|}{ Matched Firms $(n=13)$} \\
\hline & Mean & Std. Dev. & Median & Mean & Std. Dev. & Median \\
\hline TA & $9,872.670$ & $8,865.000$ & $8,271.810$ & $9,857.728$ & $9,442.000$ & $4,374.110$ \\
\hline TD & $4,410.881$ & $6,885.000$ & $2,199.400$ & $6,525.806$ & $7,582.000$ & $2,731.000$ \\
\hline REV & $7,003.652$ & $5,616.000$ & $5,257.670$ & $3,713.141$ & $3,281.000$ & $2,519.420$ \\
\hline COGS & $4,008.133$ & $5,084.000$ & $1,914.400$ & $1,249.942$ & $1,571.000$ & 476.810 \\
\hline XSGA & $1,705.168$ & 849.974 & $1,628.400$ & $1,734.974$ & $1,929.000$ & 770.480 \\
\hline CFO & $1,068.392$ & 752.359 & 934.060 & 516.576 & 455.439 & 296.380 \\
\hline LEV & 0.376 & 0.219 & 0.337 & 0.555 & 0.211 & 0.552 \\
\hline DEA & 0.881 & 0.112 & 0.875 & 0.781 & 0.061 & 0.785 \\
\hline
\end{tabular}

Paired Difference in Mean

\begin{tabular}{ccc}
\hline Variable & $\begin{array}{c}\text { t test } \\
\text { (p-value) }\end{array}$ & $\begin{array}{c}\text { Wilcoxon test } \\
\text { (p-value) }\end{array}$ \\
\hline TA & 0.9967 & 0.7609 \\
TD & 0.4638 & 0.6126 \\
REV & 0.0806 & 0.0509 \\
COGS & 0.0739 & 0.0767 \\
OEXP & 0.9598 & 0.3648 \\
CFO & 0.033 & 0.0296 \\
LEV & 0.0444 & 0.0411 \\
DEA & 0.0095 & 0.0293 \\
\hline
\end{tabular}

Variable definition:

$\mathrm{TA}=$ total assets (Compustat Item \#6) in 2005.

$\mathrm{TD}=$ total debt (Compustat Item \#9 + \#34) in 2005.

$\mathrm{REV}=$ total revenue (Compustat Item \#12) in 2005.

COGS = total cost of goods sold (Compustat Item \#41) in 2005.

XSGA = total selling, general and administrative expenses (Compustat Item \#189) in 2005.

$\mathrm{CFO}=$ total cash flow from operations (Compustat Item \#308) in 2005.

$\mathrm{LEV}=$ total debt (Compustat Item \#9 + \#34) / total assets (Compustat Item \#6).

$\mathrm{DEA}=$ efficiency score at firm level.

Table 3 presents the descriptive statistics of selected variables for sample and matched firms in the business services industry (SIC $=73$ ). The mean and median values for the efficiency score are 0.881 and 0.875 , respectively, for sample firms compared to 0.781 and 0.785 , respectively, for matched firms. This result adds support for our hypothesis. Sample firms with better reputations in the business services industry have statistically higher average efficiency scores (Wilcoxon test: $\mathrm{p}=0.0293$, t test: $\mathrm{p}=0.0095$ ). In addition, paired differences in revenue, cost of goods sold, cash flow from operations and leverage are significant.

The correlation coefficients also add support to our hypothesis. Panel A of Table 4 reports the Pearson correlation matrix for selected variables for chemical firms. These variables include reputation (REPU), efficiency (DEA), total assets (TA), revenue (REV), cash flow from operations (CFO) and leverage (LEV). The correlation coefficient between reputation and efficiency is positive $(0.3807)$ and significant $(p=0.0379)$. 
Table 4

Pearson Correlations among the Variables

\begin{tabular}{|c|c|c|c|c|c|}
\hline \multicolumn{6}{|c|}{ Panel A: Chemical Industry $(n=30)$} \\
\hline & DEA & REPU & TA & REV & CFO \\
\hline REPU & 0.3807 & & & & \\
\hline (p-value, two-tailed) & 0.0379 & & & & \\
\hline TA & 0.1150 & 0.0414 & & & \\
\hline (p-value, two-tailed) & 0.5451 & 0.8281 & & & \\
\hline REV & 0.1848 & 0.2267 & 0.9038 & & \\
\hline (p-value, two-tailed) & 0.3284 & 0.2284 & $<0.0001$ & & \\
\hline CFO & 0.1490 & 0.0642 & 0.9263 & 0.9006 & \\
\hline (p-value, two-tailed) & 0.4320 & 0.7363 & $<0.0001$ & $<0.0001$ & \\
\hline LEV & -0.0009 & -0.0528 & -0.2489 & -0.1335 & -0.2637 \\
\hline (p-value, two-tailed) & 0.9607 & 0.7819 & 0.1847 & 0.4818 & 0.1591 \\
\hline \multicolumn{6}{|c|}{ Panel B: Business Services Industry $(\mathrm{n}=\mathbf{2 6})$} \\
\hline & DEA & REPU & TA & REV & CFO \\
\hline REPU & 0.4990 & & & & \\
\hline (p-value, two-tailed) & 0.0095 & & & & \\
\hline TA & 0.1570 & 0.0009 & & & \\
\hline (p-value, two-tailed) & 0.4438 & 0.9967 & & & \\
\hline REV & 0.2708 & 0.3490 & 0.5820 & & \\
\hline (p-value, two-tailed) & 0.1809 & 0.0806 & 0.0018 & & \\
\hline CFO & 0.4313 & 0.4192 & 0.6407 & 0.4934 & \\
\hline (p-value, two-tailed) & 0.0278 & 0.0330 & 0.0004 & 0.0104 & \\
\hline LEV & -0.2555 & -0.3974 & 0.4410 & 0.3507 & -0.0653 \\
\hline (p-value, two-tailed) & 0.2077 & 0.0444 & 0.0241 & 0.0790 & 0.7515 \\
\hline
\end{tabular}

Variable definition:

DEA $=$ efficiency score at firm level.

REPU $=$ " 1 " of the firm is on the America's Most Admired Companies of 2006, otherwise, " 0 ".

$\mathrm{TA}=$ total assets (Compustat Item \#6) in 2005.

$\mathrm{CFO}=$ total cash flow from operations (Compustat Item \#308) in 2005.

$\mathrm{LEV}=$ total debt (Compustat Item \#9 + \#34) / total assets (Compustat Item \#6).

Panel B of Table 4 reports the Pearson correlation matrix for business services firms. The correlation coefficient between reputation and efficiency is also positive $(0.4990)$ and significant $(p=0.0095)$. These correlation results support our hypothesis. Reputation is significantly positively related to efficiency in both the chemical and business services industries.

\section{MODEL SPECIFICATION AND RESULTS}

\subsection{Empirical Model Specification}

We also use regression analysis to test our hypothesis. Specifically, we use the following regression model:

$\mathrm{DEA}_{\mathrm{i}}=\alpha_{0}+\alpha_{1} \mathrm{REPU}_{\mathrm{i}}+\alpha_{2} \mathrm{SIZE}_{\mathrm{i}}+\alpha_{3} \mathrm{LEV}_{\mathrm{i}}+\alpha_{4} \mathrm{IND}_{\mathrm{i}}+\varepsilon$

Where

$D_{E E A_{i}}=$ the efficiency score for firm $i$.

$\mathrm{REPU}_{\mathrm{i}}=$ a reputation indicator variable for firm i. If firm i is selected on the America's Most Admired Company List, then the value of REPU is equal to " 1 ". Otherwise, the value is " 0 ".

$\mathrm{SIZE}_{\mathrm{i}}=$ total assets for firm i (Compustat Item \#6).

$\mathrm{LEV}_{\mathrm{i}}=$ total liabilities (Compustat Item \#9 + \#34) divided by total assets (Compustat Item \#6) for firm i. 
$\mathrm{IND}_{\mathrm{i}}=$ an industry indicator variable for firm $\mathrm{i}$. If firm $\mathrm{i}$ is from the business services industry (SIC $=73$ ), $\mathrm{IND}_{\mathrm{i}}$ is equal to " 1 ". If firm $i$ is from the chemical industry $(\mathrm{SIC}=28), \mathrm{IND}_{\mathrm{i}}$ is equal to " 0 ".

A positive coefficient on REPU supports our hypothesis and indicates that firms with better reputation may operate with more technical efficiency. Three additional independent variables are included to control for size, leverage, and industry.

\subsection{Regression Results}

Table 5 reports the results of our regression analysis.

Table 5

Regression Analysis

\begin{tabular}{|c|c|c|c|c|}
\hline \multicolumn{5}{|c|}{$\frac{\text { Model: }}{\text { DEA }_{\mathrm{i}}=} \beta_{0}+\beta_{1} * \mathrm{REP}_{\mathrm{i}}+\beta_{2} * \mathrm{SIZE}_{\mathrm{i}}+\beta_{3} * \mathrm{LEV}_{\mathrm{i}}+\beta_{4} * \mathrm{IND}_{\mathrm{i}}+\varepsilon$} \\
\hline \multicolumn{5}{|c|}{$\mathrm{N}=56 ;$ Adjusted $\mathrm{R}^{2}=0.1414$} \\
\hline Variables & Parameter Estimates & Std. Error & t-stat & $\operatorname{Pr}>|\mathbf{t}|$ \\
\hline Intercept & 0.7794 & 0.0483 & 16.14 & $<0.0001 *$ \\
\hline REP & 0.0830 & 0.0249 & 3.33 & $0.0016^{*}$ \\
\hline SIZE & $6.64 \mathrm{E}-07$ & $7.91 \mathrm{E}-07$ & 0.84 & 0.4047 \\
\hline LEV & -0.0160 & 0.0583 & -0.27 & 0.7851 \\
\hline IND & 0.0115 & 0.0286 & 0.40 & 0.6889 \\
\hline
\end{tabular}

* significant at 0.01 or better, two-tailed test.

\section{Variable definitions:}

$D_{E A}=$ the efficiency score for firm $i$.

$\mathrm{REPU}_{\mathrm{i}}=$ a reputation indicator variable for firm $\mathrm{i}$. If firm $\mathrm{i}$ is selected on the America's Most Admired Company List, then the value of $\operatorname{REPU}_{\mathrm{i}}$ is equal to " 1 ". Otherwise, the value is " 0 ".

$\mathrm{SIZE}_{\mathrm{i}}=$ total assets for firm i (Compustat Item \#6).

$\mathrm{LEV}_{\mathrm{i}}=$ total liabilities (Compustat Item \#9 + \#34) divided by total assets (Compustat Item \#6) for firm $\mathrm{i}$.

$\mathrm{IND}_{\mathrm{i}}=$ an industry indicator variable for firm $\mathrm{i}$. If firm $\mathrm{i}$ is from the business services industry $(\mathrm{SIC}=73$ ), $\mathrm{IND}_{\mathrm{i}}$ is equal to " 1 ". If firm $\mathrm{i}$ is from the chemical industry $(\mathrm{SIC}=28), \mathrm{IND}_{\mathrm{i}}$ is equal to " 0 ".

The regression results strongly support our hypothesis. Reputation's regression coefficient $\left(\beta_{1}\right)$ is positive $(0.0830)$ and strongly significant $(\mathrm{p}=0.0016)$ indicating a positive relationship between reputation and performance efficiency. Results indicate that DEA efficiency scores are positively related to size and negatively related to leverage. However, both control variables are not significant. The model's adjusted $\mathrm{R}^{2}$ is 0.1414 .

\section{CONCLUSION}

This study examines the association between corporate reputation and firm efficiency. We posit that firms with superior reputation operate with more performance efficiency. Using correlations, mean comparisons and regression analysis, this study finds evidence to support our hypothesis. Future work can expand the results of this initial study in a number of ways. For example, future work can examine other industries or time periods. Future work could also explore the relationship between firm reputation and other performance variables. Given the growing importance of reputation in our interconnected and expanding economy, extending this work would be relevant and useful.

\section{AUTHOR INFORMATION}

Martin T. Stuebs, Jr. is an Assistant Professor of Accounting at Baylor University in Waco, Texas. He received his doctoral degree from the University of Arkansas. He has published articles in several journals including the CPA Journal, the Journal of Accounting and Public Policy, and Issues in Accounting Education. 
Li Sun is an Assistant Professor of Accounting at Ball State University. He earned his Ph.D. in Business Administration from Oklahoma State University. He has published an article in Journal of Forensic Accounting.

\section{REFERENCES}

1. Anderson, J., \& Smith, G. N. (2006). A great company can be a great investment. Financial Analysts Journal, 62(4), 86-93.

2. Banker, R.D., Charnes, A., \& Cooper, W. W. (1984). Some Models for Estimating Technical and Scale Inefficiencies in Data Envelopment Analysis. Management Science, 30, 1078-1092.

3. Battese, G. E., \& Coelli, T. J. (1995). A Model for Technical Inefficiency Effects in a Stochastic Frontier Production Function for Panel Data. Empirical Economics, 20, 325-332.

4. Charnes, A., Cooper, W. W., \& Rhodes, E. (1978). Measuring the Efficiency of Decision Making Units. European Journal of Operational Research, 2, 429-444.

5. Cooper, W. W., Seiford, L. M., \&Tone, K. (2000). Data Envelopment Analysis: A Comprehensive Text with Models, Applications, References and DEA-Solver Software. Kluwer Academic Publishers, Boston, MA.

6. Feroz, E. H., Goel, S., \& Raab, R. L. (2008). Performance measure for accountability in corporate governance: a data envelopment analysis approach. Review of Accounting and Finance, 7, 121-130.

7. Damodaran, A. (2003). In search of excellence! Are good companies good investments? Working Paper, New York University.

8. Dierickx, I. \& Cool, K. (1989). Asset stock accumulation and sustainable competitive advantage. Management Science 35:1504-1511.

9. Dowling, G. (2001). Creating corporate reputations. Oxford University Press: Oxford.

10. Fombrun, C. (1996). Reputation: realizing value from the corporate image. Harvard Business School Press: Boston, MA.

11. Fombrun, C. \& Shanley, M. (1990). What's in a name? Reputation building and corporate strategy. Academy of Management Journal, 33, 233-258.

12. Griffin, J. J. \& Mahon, J. F. (1997). The corporate social performance and corporate financial performance debate: Twenty-Five years of incomparable research. Business \& Society, 36:1, 5-31.

13. Herremans, I. M., Akathaporn, P., \& McInnes, M. (1993). An investigation of corporate social responsibility reputation and economic performance. Accounting Organizations and Society, 18, 587-604.

14. Landon, S., \& Smith, C. E. (1997). The use of quality and reputation indicators by consumers: the case of Bordeaux wine. Journal of Consumer Policy, 20, 289-323.

15. Luchs, C., Stuebs, M., \& Sun, L. (2009). Corporate Reputation and Earnings Quality. Journal of Applied Business Research, 25:4, forthcoming.

16. McLaughlin, R. M., Ruback, R., \& Tehranian, H. (1996). Does corporate quality matter? Working paper, Suffolk University.

17. Roberts, P. \& Dowling, G. (2002). Corporate reputation and sustained superior financial performance. Strategic Management Journal, 23, 1077-1093.

18. Simpson, W. G. \& Kohers, T. (2002) The link between corporate social and financial performance: Evidence from the banking industry. Journal of Business Ethics, 35, 97-109.

19. Wang, K., \& Smith, L. (2008). Does corporate reputation translate into higher market value? Working paper, Texas Southern University.

\section{NOTES}

1. In efficiency studies, the observational unit is called a DMU (Decision Making Unit). In general, a DMU is an entity that is responsible for converting inputs into outputs. DMUs may include schools, firms, banks, hospitals and so forth.

2. The output/input ratio of point $\mathrm{F}$ is FH/GF, while the output/input ratio of point $\mathrm{E}$ is $\mathrm{EJ} / \mathrm{GE}$. Thus, the relative efficiency of point $\mathrm{E}$ is $(\mathrm{EJ} / \mathrm{GE}) /(\mathrm{FH} / \mathrm{GF})=\mathrm{GF} / \mathrm{GE}$

3. http://money.cnn.com/magazines/fortune/mostadmired/2006/index.html

4. We consider firms within the same two-digit SIC code to be "within the same industry". 
NOTES 